\title{
ZANIECZYSZCZENIE GLEBY LUB ZIEMI FENOLEM JAKO PRZESŁANKA WYSTĄPIENIA SZKODY W POWIERZCHNI ZIEMI
}

\section{CONTAMINATION OF SOIL OR GROUND WITH PHENOL AS THE CONDITION FOR THE OCCURRENCE OF DAMAGE IN THE SURFACE OF THE EARTH}

http://dx.doi.org/10.12775/PPOS.2015.030

\section{STRESZCZENIE}

W niniejszym artykule, przyjmując za aktualny stan prawny obowiązujący na dzień 19 marca 2015 roku, jak również uwzględniając planowane zmiany aktów normatywnych regulujących zagadnienie szkody w środowisku, przeanalizowano znaczenie standardów jakości

* Magister prawa, magister inżynier ochrony środowiska, doktorantka w Instytucie Nauk Prawnych Polskiej Akademii Nauk. 
gleby i ziemi dla możliwości stwierdzenia wystąpienia szkody w powierzchni ziemi.

Dla zilustrowania rozważań odnoszących się do kryteriów wystąpienia takiej szkody, ale także uwypuklenia trudności związanych z prawidłową oceną jej wystąpienia, przeprowadzono case study bazujące na wybranym zanieczyszczeniu.

Odwołując się do właściwości czy specyfiki fenolu jako powszechnie stosowanej substancji chemicznej, dowiedziono w przekonaniu autora, iż prawidłowa ocena wystąpienia szkody w powierzchni ziemi, a także wskazanie podmiotów za nią odpowiedzialnych, stanowi wymagający posiłkowania się wiedzą specjalistyczną, skomplikowany proces o interdyscyplinarnym charakterze.

\section{Słowa kluczowe}

Zanieczyszczenie gleby; fenol; standardy jakości gleby i ziemi; szkoda w środowisku; szkoda w powierzchni ziemi.

\section{ABSTRACT}

The article presents the analysis of the significance of soil and ground quality standards for the possibility of stating the occurrence of damage in the surface of the earth, accepting the current legislation in force as at 19 March 2015, as well as taking into consideration the planned amendments of normative acts regulating the issue of damage in the environment.

To illustrate the considerations pertaining to the criteria of the occurrence of such damage, as well as to highlight the difficulties connected with the correct assessment of its occurrence, a case study was conducted based on selected contamination.

With reference to the properties and the specificity of phenol as a commonly used chemical substance, it has been proved, according to the author, that the correct assessment of the occurrence of damage in the surface of the earth, as well as the indication of entities responsible for it, constitutes a complex, interdisciplinary process that requires specialist expertise.

\section{Keywords}

Soil contamination; phenol; soil and ground quality standards; environmental damage; damage in the surface of the earth. 


\section{POJĘCIE SZKODY W POWIERZCHNI ZIEMI}

Przystępując do rozważań na temat przesłanek determinujących wystąpienie szkody $\mathrm{w}$ powierzchni ziemi, zasadne przede wszystkim wydaje się zdefiniowanie samego pojęcia szkody w powierzchni ziemi oraz określenie jej charakterystycznych elementów. Wskazać należy, iż po raz pierwsz, polski ustawodawca zdefiniował pojęcie szkody w środowisku w ustawie z dnia 13 kwietnia 2007 r. o zapobieganiu szkodom w środowisku i ich naprawie ${ }^{1}$, która dokonała transpozycji do porządku krajowego regulacji dyrektywy 2004/35 Parlamentu Europejskiego i Rady z dnia 21 kwietnia 2004 r. w sprawie odpowiedzialności za środowisko w odniesieniu do zapobiegania czi zaradzania szkodom wyrządzonym środowisku naturalnemu².

Zgodnie z art. 6 pkt 11 lit c u.z.s.w.ś. szkoda w środowisku oznacza „negatywną, mierzalną zmianę stanu lub funkcji elementów przyrodniczych, ocenioną w stosunku do stanu początkowego, która została spowodowana bezpośrednio lub pośrednio przez działalność prowadzoną przez podmiot korzystający ze środowiska", przez co, w odniesieniu do powierzchni ziemi, ustawodawca rozumie zanieczyszczenie gleby lub ziemi, w tym w szczególności zanieczyszczenie mogące stanowić zagrożenie dla zdrowia ludzi.

W doktrynie wielokrotnie już akcentowano ${ }^{3}$, że szkoda w środowisku, w tym - co oczywiste - również szkoda w powierzchni ziemi w rozumieniu ustawy szkodowej może być spowodowana jedynie przez ustawowo zakreślony krąg podmiotów

1 T.j. Dz.U. z 2014 r., poz. 1789 ze zm. (dalej cyt.: u.z.s.w.ś. lub Ustawa szkodowa).

2 Dz. Urz. UE L 143 z 30.04.2004, s. 56-75 (dalej cyt.: Dyrektywa 2004/35/WE).

3 K. Kwaśnicka, Odpowiedzialność administracyjna $w$ prawie ochrony środowiska, Warszawa 2011, s. 169-170; M. Górski, Odpowiedzialność administracyjnoprawna $w$ ochronie środowiska, Warszawa 2008, s. 34-40; B. Rakoczy, Komentarz do ustawy o zapobieganiu szkodom $w$ środowisku u ich naprawie, Warszawa 2008, s. 47-48. 
korzystających ze środowiska, przy czym autorzy ${ }^{4}$ konsekwentnie wskazują nadto na konieczność wystąpienia związku przyczynowo skutkowego pomiędzy działaniami prowadzonymi przez takie podmioty, a skutkiem przejawiającym się wystąpieniem szkody w środowisku, w tym szkody w powierzchni ziemi.

$\mathrm{Na}$ tle przywołanej definicji nasuwa się pytanie o to, w jakich przypadkach należy uznać, że wystąpiło zanieczyszczenie gleby lub ziemi, w tym - w szczególności, kiedy zanieczyszczenie takie będzie mogło stanowić zagrożenie dla zdrowia ludzi. W odpowiedzi pomocne wydają się postanowienia art. 101a ust. 1-2 Ustawy z dnia z dnia 27 kwietnia 2001 r. Prawo ochrony środowiska $^{5}$, w którym ustawodawca wskazał, że zanieczyszczenie powierzchni ziemi ocenia się na podstawie przekroczenia dopuszczalnych zawartości substancji powodujących ryzyko w glebie lub w ziemi ${ }^{6}$, a zatem zawartości poniżej której żadna z funkcji pełnionych przez powierzchnię ziemi nie jest znacząco naruszona, z uwzględnieniem wpływu tej substancji na zdrowie

4 B. Rakoczy, Cywilnoprawne aspekty ustawy o zapobieganiu szkodom $w$ środowisku $i$ ich naprawie, „Studia z zakresu prawa, administracji i zarządzania Uniwersytetu Kazimierza Wielkiego w Bydgoszczy” 2013, vol. 3, s. 16. Autor wprost wskazuje, że „wprawdzie ustawodawca w ustawie szkodowej nie odwołuje się bezpośrednio do związku przyczynowego, niemniej jednak nie ma żadnej wątpliwości, że taki związek pomiędzy zachowaniem podmiotu korzystającego ze środowiska, a szkodą w środowisku lub bezpośrednim zagrożeniem szkodom w środowisku, musi istnieć".

5 T. j. Dz.U. z 2013 r., poz. 1232 ze zm. (dalej cyt.: u.p.o.ś).

6 Pojęcie „substancji powodującej ryzyko" zostało zdefiniowane w art. 3 pkt 37a u.p.o.ś. Zgodnie z definicją wskazaną $\mathrm{w}$ tym przepisie pod pojęciem substancji powodującej ryzyko należy rozumieć substancję stwarzającą zagrożenie i mieszaninę stwarzającą zagrożenie, należącą co najmniej do jednej z klas zagrożenia wymienionych w częściach 2-5 załącznika I do Rozporządzenia Parlamentu Europejskiego i Rady (WE) nr 1272/2008 z dnia 16 grudnia 2008 r. w sprawie klasyfikacji, oznakowania i pakowania substancji i mieszanin, zmieniającego i uchylającego Dyrektywy 67/548/EWG i 1999/45/WE oraz zmieniającego Rozporządzenie (WE) nr 1907/2006 (Dz. Urz. UE L 353 z 31.12.2008, s. 1 ze zm.), w szczególności substancje powodujące ryzyko, o których mowa w przepisach wydanych na podstawie art. 101a ust. 5 pkt 1; definicja została dodana przez art. 1 pkt 2 lit. j Ustawy z dnia 11 lipca 2014 r. o zmianie Ustawy Prawo ochrony środowiska oraz niektórych innych ustaw (Dz.U. z 2014 r., poz. 1101) i w tym brzmieniu obowiązuje od dnia 5 września 2014 r. 
ludzi i stan środowiska. W ust. 3 przywołanego art. 101a u.p.o.ś ustawodawca przesądził również, że o ile inna funkcja nie wynika z planu zagospodarowania przestrzennego, funkcję pełnioną przez powierzchnię ziemi należy oceniać na podstawie jej faktycznego zagospodarowania czy wykorzystania.

Należy zwrócić uwagę również na fakt, że - aby w ogóle można było mówić o szkodzie w powierzchni ziemi, ewentualne zanieczyszczenie gleby lub ziemi powinno zostać ocenione w stosunku do stanu początkowego, a zatem stanu, który ustawodawca również zdefiniował w ustawie szkodowej. Zgodnie z art. 6 pkt 10 u.z.s.w.ś. stan początkowy, to oszacowany na podstawie dostępnych informacji „stan i funkcje środowiska oraz poszczególnych elementów przyrodniczych przed wystąpieniem szkody w środowisk". Jednocześnie ustawodawca doprecyzował, że w przypadku szkody w środowisku w powierzchni ziemi, stan początkowy to w szczególności stan określony w raporcie początkowym, albo, jeżeli nie ma dostępnych informacji na temat stanu początkowego lub w raporcie początkowym stwierdzono przekroczenie dopuszczalnych zawartości substancji powodujących ryzyko, stan zgodny z dopuszczalnymi zawartościami substancji powodujących ryzyko.

Na podstawie obligatoryjnego upoważnienia wyrażonego w art. 101a ust. 5 u.p.o.ś, substancje powodujące ryzyko szczególnie istotne dla ochrony powierzchni ziemi, ich dopuszczalne zawartości w glebie oraz dopuszczalne zawartości w ziemi, zróżnicowane dla poszczególnych właściwości gleby oraz grup gruntów, wydzielonych w oparciu o sposób ich użytkowaniama - w drodze rozporządzenia - określić minister właściwy do spraw środowiska. W stanie prawnym aktualnym na dzień 19 marca 2015 rok, prace nad przygotowaniem treści takiego aktu są wprawdzie prowadzone ${ }^{7}$, jednak ostateczne brzmienie rozporządzenia nie zostało jeszcze przyjęte. Powyższe nie oznacza jednak legislacyjnej pustki, zgodnie bowiem z art. 15 ustawy z dnia 11 lipca 2014 r. o zmianie ustawy Prawo ochrony śro-

7 Projekt Rozporządzenia Ministra Środowiska w sprawie oceny zanieczyszczenia powierzchni ziemi został przedłożony Sejmowi Rzeczypospolitej Polskiej w dniu 14 lutego 2014 r. - druk nr 2162 cz. 2; www.sejm.gov.pl. 
dowiska oraz niektórych innych ustaw ${ }^{8}$, do dnia wejścia w życie przepisów wykonawczych wydanych na podstawie art. 101a ust. 5 u.p.o.ś, za dopuszczalne zawartości w glebie i w ziemi substancji powodujących ryzyko uważa się standardy jakości gleby oraz standardy jakości ziemi określone w przepisach dotychczasowych.

Kluczowym elementem normatywnym, który - jak podkreśla B. Rakoczy ${ }^{9}$ - „kształtuje odpowiedzialność za szkody w środowisku"- jest rozporządzenie określające kryteria oceny, czy w danym przypadku wystąpiła szkoda w środowisku. Takie rozporządzenie kierując się potrzebą zapewnienia odpowiedniego poziomu ochrony środowiska, na podstawie upoważnienia zawartego w art. 10 u.z.s.w.ś., wydał w dniu 30 kwietnia 2008 r. Minister Środowiska ${ }^{10}$. W literaturze przedmiotu ${ }^{11}$ wyraźnie akcentuje się istotne znaczenie i konsekwencje treści wskazanego rozporządzenia dla podmiotów korzystających ze środowiska. Jak podkreślają W. Federczyk i A. Kosieradzka-Federczyk $^{12}$, „znaczenie rozporządzenia jest bardzo duże, bowiem tylko wtedy, gdy nastąpi jedno ze zdarzeń w nim opisanych, będzie można uznać, że została spełniona jedna z przesłanek szkody w środowisku".

Jak stanowi $\S 5$ k.o.w.s.w.ś., kryterium oceny wystąpienia szkody w środowisku w powierzchni ziemi jest zmiana lub zmiany powodujące przekroczenie standardów jakości gleby lub ziem, bądź konieczność zmiany dotychczasowego sposobu wykorzystania powierzchni ziemi, jak również zaistnienie obu wskazanych w przywołanym przepisie przesłanek równo-

8 Ustawa z dnia 11 lipca 2014 r. o zmianie Ustawy Prawo ochrony środowiska oraz niektórych innych ustaw, Dz.U. z 2014 r., poz. 1101 (dalej cyt.: u.z.p.o.ś.).

9 B. Rakoczy, Komentarz do ustawy, s. 80.

10 Rozporządzenie Ministra Środowiska z dnia 30 kwietnia 2008 r. w sprawie kryteriów oceny wystąpienia szkody w środowisku, Dz.U. Nr 82, poz. 501 (dalej cyt.: k.o.w.s.w.ś.) lub Rozporządzenie w sprawie kryteriów wystąpienia szkody.

11 B. Rakoczy, Komentarz do ustawy, s. 80.

12 W. Federczyk, A. Kosieradzka-Federczyk, Ustawa o zapobieganiu szkodom $w$ środowisku i ich naprawie. Komentarz, LEX/el. 2013. 
cześnie, o czym przesądza wprowadzone przez ustawodawcę sformułowanie ,jeden lub więcej z następujących mierzalnych skutków". Z uwagi na zmiany jakie dokonały się w obowiązujących przepisach za sprawą u.z.p.o.ś. podkreślenia wymaga, że w najbliższym czasie zmianie ulegną również kryteria oceny wystąpienia szkody w środowisku. Należy wskazać, że - zgodnie z art. 9 oraz art. 38 pkt 1 u.z.p.o.ś, - dotychczas obowiązujące rozporządzenie w sprawie kryteriów wystąpienia szkody, zachowa moc do dnia wejścia w życie nowych przepisów wykonawczych regulujących to zagadnienie, jednak nie dłużej niż do 6 września 2016 roku.

Dokonując rekapitulacji poczynionych spostrzeżeń, wskazać zatem należy, że analizując możliwość wystąpienia szkody w powierzchni ziemi w stanie prawnym aktualnym na dzień 19 marca 2015 roku, ewentualne zanieczyszczenie gleby lub ziemi powinno zostać ocenione w stosunku do stanu zgodnego ze standardami jakości gleby oraz standardami jakości ziemi, które - z uwzględnieniem aktualnej i planowanej funkcji terenu, zostały określone w rozporządzeniu Ministra Środowiska z dnia 9 września 2002 r. w sprawie standardów jakości gleby oraz standardów jakości ziemi ${ }^{13}$.

\section{STANDARDY JAKOŚCI GLEBY ORAZ STANDARDY JAKOŚCI ZIEMI JAKO KRYTERIUM OCENY WYSTĄPIENIA SZKODY W POWIERZCHNI ZIEMI}

Zgodnie z § 1 ust. 1 rozporządzenia w sprawie standardów jakości gleby i ziemi, co do zasady glebę lub ziemię uznaje się za zanieczyszczoną, gdy stężenie co najmniej jednej substancji, którą wskazał ustawodawca, przekracza wartość dopuszczalną.

13 Rozporządzenie Ministra Środowiska z dnia 9 września 2002 r. w sprawie standardów jakości gleby oraz standardów jakości ziemi, Dz.U. z 2002 r. Nr 165, poz. 1359 (dalej cyt.: s.j.g.i.z.) lub Rozporządzenie w sprawie standardów jakości gleby i ziemi. 
Warto nadmienić, iż inne dopuszczalne stężenia metali ciężkich mogą obowiązywać na glebach znajdujących się na terenach gospodarstw, w których może być prowadzona produkcja rolna metodami ekologicznymi. W odniesieniu do tych gleb, dopuszczalne stężenia metali ciężkich określają bowiem przepisy o rolnictwie ekologicznym, do których wprawdzie nie odsyła wprost rozporządzenie s.j.g.i.z., lecz jak można jednak sądzić, będą to w głównej mierze przepisy rozporządzenia 834/20074, przepisy wydane $\mathrm{w}$ trybie przepisów tego rozporządzenia oraz przepisy ustawy o rolnictwie ekologicznym ${ }^{15}$ czy aktów wykonawczych do niej. Na takie rozumienie przepisów o rolnictwie ekologiczny, wskazuje bowiem art. 2 pkt 5 u.r.e.

W załączniku do rozporządzenia s.j.g.i.z. ustawodawca określił dopuszczalne wartości stężeń w glebie lub ziemi dla 57 substancji, które zostały wymienione w sześciu wyodrębnionych grupach. Odnosząc się do kompletności wyliczenia zawartego w załączniku do rozporządzenia s.j.g.i.z., w pełni zgodzić należy się z poglądem prezentowanym przez W. Szczukę-Skarżyńską ${ }^{16}$, która zauważa, że wykaz ten jest wyczerpujący, co na tle przywołanych uprzednio aktów normatywnych regulujących zagadnienie szkody w powierzchni ziemi prowadzi do konstatacji, iż w przypadku występowania w glebie lub ziemi substancji nie wymienionych $\mathrm{w}$ załączniku do rozporządzenia $\mathrm{w}$ sprawie standardów jakości gleby i ziem, nie można mówić o szkodzie w rozumieniu art. 6 pkt 11 lit. c u.z.s.w.s. Stosowanie w takiej sytuacji wykładni rozszerzające, czy też odwoływanie się poprzez analogię do innych „podobnych substancji” lub substancji „o zbliżonych właściwościach” do tych, które zostały wymienione w załączniku do rozporządzenia s.j.g.i.z.- należy uznać za niedopuszczalne.

14 Rozporządzenie Rady (WE) nr 834/2007 z dnia 28 czerwca 2007 r. w sprawie produkcji ekologicznej i znakowania produktów ekologicznych i uchylające Rozporządzenie (EWG) nr 2092/91, Dz. Urz. UE L 189 z 20.07.2007, s. 1-2 (dalej cyt.: Rozporządzenie nr 834/2007).

15 Ustawa z dnia 25 czerwca 2009 r. o rolnictwie ekologicznym, Dz.U. Nr 116, poz. 975 ze zm. (dalej cyt.: u.r.e.).

16 W. Szczuka-Skarżyńska, Nasze wspólne dobro, „Rzeczpospolita” $2003 / 7 / 2$ 
Jak podkreśla B. Rakoczy ${ }^{17}$, „powierzchnia ziemi pełni określone funkcje”, zatem standardy jej jakości „powinny być ustalone na takim poziomie, aby żadna z tych funkcji nie została naruszona". Powyższe ustawodawca realizuje poprzez wyszczególnienie $\mathrm{w}$ rozporządzeniu s.j.g.i.z. trzech rodzajów gruntów, dla których w różny sposób ustalone zostały standardy. Odrębnie określono wartości stężeń poszczególnych substancji dla obszarów chronionych ${ }^{18}$, charakteryzowanych jako grupa „A", odmiennie dla gruntów zaliczonych do użytków rolnych ${ }^{19}$, gruntów leśnych, zadrzewionych, zakrzewionych, nieużytków, a także gruntów zabudowanych i zurbanizowanych ${ }^{20}$, charakteryzowanych jako grupa „B”, a inne dla terenów przemysłowych, użytków kopalnych czy terenów komunikacyjnych, które stanowią grupę „C".

Analizując treść rozporządzenia s.j.g.i.z, w kontekście dalszych rozważań, na szczególną uwagę zasługuje przepis $\S 1$ ust. 4, który wskazuje na konieczność przyjęcia swego rodzaju fikcji prawnej w sytuacji, gdy przekroczenie wartości dopuszczalnej stężenia substancji w badanej glebie lub ziemi wynika $\mathrm{z}$ naturalnie wysokiej jej zawartości $\mathrm{w}$ środowisku. W takich przypadkach, zgodnie z brzmieniem przywołanej regulacji, uważa się, że przekroczenie dopuszczalnej wartości stężeń w glebie lub ziemi nie nastąpiło ${ }^{21}$.

17 B. Rakoczy, Komentarz do art.103 ustawy - Prawo ochrony środowiska, w: Z. Bukowski, E. K. Czech, K. Karpus, B. Rakoczy, Prawo ochrony środowiska. Komentarz, Warszawa 2013, s. 167.

18 Chodzi tu zarówno o nieruchomości gruntowe wchodzące w skład obszaru poddanego ochronie na podstawie przepisów Ustawy Prawo wodne, jak i obszary poddane ochronie na podstawie przepisów o ochronie przyrody; jeżeli utrzymanie aktualnego poziomu zanieczyszczenia gruntów nie stwarza zagrożenia dla zdrowia ludzi lub środowiska.

19 Z wyłączeniem gruntów pod stawami i gruntów pod rowami.

20 Z wyłączeniem terenów przemysłowych, użytków kopalnych oraz terenów komunikacyjnych.

21 Analogiczna konstrukcja została wprowadzona bezpośrednio do u.p.o.ś. za sprawą dodanego przez art. 1 pkt 12 Ustawy z dnia 11 lipca 2014 r. o zmianie Ustawy Prawo ochrony środowiska oraz niektórych innych ustaw, art. 101a. ust. 4, który stanowi, że „gleby, ziemi lub wód gruntowych nie uzna- 
Na tle poczynionych uprzednio spostrzeżeń należy zatem stwierdzić, iż szkoda w powierzchni ziemi nie wystąpi, jeżeli przekroczenie dopuszczalnej wartości stężeń w glebie lub ziemi będzie w konkretnej sytuacji wynikało z naturalnie wysokiej zawartości danej substancji w środowisku - w takim bowiem przypadku nie można mówić o przekroczeniu standardów.

Mając na uwadze powyższe, dla oceny, czy w danej sytuacji wystąpiła szkoda w powierzchni ziemi, kluczowe wydaje się zatem nie tylko określenie stężeń danej substancji w glebie lub ziemi, lecz również prawidłowe wskazanie źródła pochodzenia zanieczyszczeń ze szczególnym uwzględnieniem źródeł naturalnych. O ile w przypadku niektórych obszarów i wybranych zanieczyszczeń, dostępne dane literaturowe ${ }^{22}$ pozwalają w dość jednoznaczny sposób stwierdzić ich naturalne pochodzenie lub choćby z pewnym prawdopodobieństwem ${ }^{23}$ założyć taki wariant, o tyle w przypadku innych, nie zawsze jest to możliwe i może stanowić istotny problem w ocenie wystąpienia szkody w powierzchni ziemi.

je się za zanieczyszczone, jeżeli stwierdzone w niej zawartości substancji są pochodzenia naturalnego".

22 K. Bojarska, Z. Bzowski, Monitoring środowiska rejonie składowiska odpadów komunalnych $w$ Zakopanem, „Ochrona Środowiska i Zasobów Naturalnych" 2009, nr 40, s. 640. Autorzy wskazują, że zwiększone ilości baru w warstwie glebowo-gruntowej badanych gleb na Podhalu wynikają z naturalnych jego zawartości.

23 A. Bogda, Mineralogiczne i mikromorfologiczne badania produktów wietrzenia niektórych magmowych skał macierzystych gleb występujących $w$ Sudetach, „Roczniki Gleboznawcze” 1973, nr 2, s. 85-132. Autor publikacji wskazuje, że podwyższona koncentracja ołowiu, cynku i kadmu na terenie Kotliny Jeleniogórskiej może wynikać z uwarunkowań naturalnych; K. Mazurski, Fitogeniczne gleby Sudetów w świetle badań masowych, „Roczniki Gleboznawcze” 1978, nr 2, s. 98-112. Podobnie jak A. Bogda autor wskazuje, że przyczyną podwyższonej koncentracji ołowiu, cynku i kadmu na terenie Kotliny Jeleniogórskiej może być występowanie na tym obszarze skał wietrzeniowych i metamorficznych. 


\section{FENOL JAKO SUBSTANCJA POWODUJĄCA RYZYKO W GLEBIE I W ZIEMI}

Ilustrując powyższe rozważania przykładem, przeanalizowano określone $\mathrm{w}$ aktualnie obowiązującym rozporządzeniu s.j.g.i.z. dopuszczalne wartości stężenia w glebie lub ziemi dla fenolu, jako substancji powszechnie stosowanej ${ }^{24}$ zarówno w przemyśle chemicznym ${ }^{25}$, w gospodarstwach domowych ${ }^{26}$, jak też występującej w stanie naturalnym ${ }^{27}$.

Wskazać należy, że fenol został wymieniony w załączniku do rozporządzenia w grupie VI, obejmującej „pozostałe zanieczyszczenia", w wierszu 5. Nie zgłębiając nadto przepisów rozporządzenia $\mathrm{w}$ sprawie standardów jakości gleby i ziemi $\mathrm{w}$ aspekcie przynależnym raczej do nauk właściwych chemii, na uwagę zasługuje fakt, iż fenol jest ściśle określoną, charakteryzowaną indywidualnym numerem $\mathrm{CAS}^{28}$, substancją chemiczną,

24 M. Michałowski, Analiza zanieczyszczeń związkami fenolowymi górnego dorzecza Raby i Dunajca oraz ustalenie źródeł emisji tych związków, „Inżynieria Mineralna” 2011, nr 1, s. 20. Autor wyróżnia dwie grupy źródeł emisji fenolu: naturalne i będące efektem działalności człowieka, tj. związane z przemysłem, rolnictwem, turystyką i rekreacją. Źródłami zanieczyszczeń punktowych wg M. Michałowskiego są głównie zrzuty ścieków odprowadzanych wylotami komunalnymi.

25 Centralny Instytut Ochrony Pracy - Państwowy Instytut Badawczy wskazuje na szerokie zastosowanie fenolu przede wszystkim jako półprodukt, m.in. przy produkcji bisfenolu A, żywic fenolowo-formaldehydowych, kaprolaktamu, alkilofenoli, kwasów salicylowych, nitrofenoli i innych substancji chemicznych, http://archiwum.ciop.pl/11582.html [dostęp: 19 marca 2015].

26 CIOP-PIB wskazuje na szerokie zastosowanie fenolu jako środka dezynfekującego w sanitarnych środkach czyszczących, a także w takich preparatach medycznych, jak: maści, krople do oczu i nosa, płyny do płukania ust czy płyny antyseptyczne, http://archiwum.ciop.pl/11582.html [dostęp: 19 marca 2015].

27 J. Kaleta, D. Papciak, A. Puszkarewicz, Ocena przydatności iłołupków bentonitowych do usuwania fenolu z roztworów wodnych, „Rocznik Ochrona Środowiska" 2013, vol. 15, s. 2352.

28 CAS - ang. Chemical Abstracts Service. Zgodnie z pkt 45 Rozporządzenia Parlamentu Europejskiego i Rady (WE) nr 1272/2008 z dnia 16 grudnia 2008 r. w sprawie klasyfikacji, oznakowania i pakowania substancji i mieszanin, zmieniające i uchylające Dyrektywy 67/548/EWG i 1999/45/WE 
w odróżnieniu od np. krezol, czy ftalanów, które wymienione zostały odpowiednio w wierszu 6 i 7 w grupie VI oraz obejmują pewne grupy substancji. Powyższe oznacza, że w przypadku np. krezoli lub ftalanów, z naruszeniem standardu jakości gleby lub ziemi, będziemy mieli do czynienia w momencie przekroczenia dopuszczalnych stężeń w odniesieniu do sumy związków, które przynależą do grupy określanej mianem krezol, lub ftalanów, natomiast w przypadku fenolu, ewentualne naruszenie dotyczyć może jedynie samego fenolu, a nie związków fenolowych ${ }^{29}$, pochodnych fenolu, czy sumy fenoli wyrażanych za pomocą tzw. indeksu fenolowego ${ }^{30}$. Sformułowanie „fenole”, które odnosić się będzie do bardzo szerokiej grupy, obejmującej liczne związki chemiczne, nie może być zatem utożsamiane z pojęciem „fenol"31 - jednoznacznie wskazującym na indywidualnie określoną substancję chemiczną o specyficznych właściwościach, której obecność w glebie lub ziemi może stanowić przesłankę wystąpienia szkody w powierzchni ziemi.

Powyższe spostrzeżenie $\mathrm{w}$ odniesieniu do ewentualnej szkody $\mathrm{w}$ powierzchni ziemi uznać należy za istotne, gdyż, w stosunku do innych komponentów środowiska w tym

oraz zmieniające Rozporządzenie (WE) nr 1907/2006 (Dz. Urz. UE L 353 z 31.12.2008, s. 1, dalej cyt.: Rozporządzenie nr 1272/2008) serwis naukowo-informacyjny Chemical Abstracts Service (CAS) prowadzi system, za pomocą którego substancje są umieszczane w rejestrze CAS i nadawany jest im niepowtarzalny numer rejestru CAS. Numery CAS wykorzystywane są na całym świecie w bazach danych i dokumentach dotyczących przestrzegania przepisów do identyfikowania substancji bez potrzeby posługiwania się istniejącym różnorodnym nazewnictwem chemicznym.

29 Zgodnie z definicją zawartą w pkt 3.1 Polskiej Normy, Jakość wody. Oznaczanie indeksu fenolowego. Metody spektrometryczne z 4 - aminoantypiryna po destylacji, PN-ISO 6439:1994 (dalej cyt.: PN-ISO 6439:1994), związki fenolowe oznaczają hydroksy pochodne benzenu i jego analogów.

30 Zgodnie z definicją zawartą w pkt 3.2. PN-ISO 6439:1994 indeks fenolowy to liczba określająca stężenie różnych związków fenolowych, a zatem nie tylko czystego fenolu.

31 Fenol jest bezbarwnym, krystalicznym ciałem stałym o ostrym zapachu. Substancja ta jest dobrze rozpuszczalna w wodzie oraz rozpuszczalnikach organicznych takich jak: etanol, eter dietylowy, gliceryna, benzen czy chloroform. CIOP-PIB [online], http://archiwum.ciop.pl/11582.html [dostęp: 19 marca 2015]. 
w szczególności wód, ustawodawca przyjął w tym względzie odmienne kryteria. Jako przykład wskazać należy Rozporządzenie Ministra Środowiska z dnia 27 listopada 2002 r. w sprawie wymagań, jakim powinny odpowiadać wody powierzchniowe wykorzystywane do zaopatrzenia ludności w wodę przeznaczoną do spożycia ${ }^{32}$, w załączniku którego, jako wskaźnik jakości wody wskazuje się nie na czysty fenol, lecz na fenole, odwołując się równolegle do uprzednio zdekodowanego już pojęcia „indeks fenolowy”33. Podobnie wszystkie związki fenolowe (nie sam fenol), ustawodawca przyjął jako wskaźnik jakości w odniesieniu do wód śródlądowych będących środowiskiem życia ryb łososiowatych i karpiowatych w warunkach naturalnych ${ }^{34}$. Analizując treść normy PN-ISO 6439:1994³5, w której podaje

32 Rozporządzenie Ministra Środowiska z dnia 27 listopada 2002 r. w sprawie wymagań, jakim powinny odpowiadać wody powierzchniowe wykorzystywane do zaopatrzenia ludności w wodę przeznaczoną do spożycia (Dz.U. z 2002 r. Nr 204, poz. 1728, dalej cyt.: w.w.p.d.z.l.w.). Zgodnie z § 4 pkt 2 k.o.w.s.w.ś. kryterium oceny wystąpienia szkody w środowisku w wodach jest zmiana lub zmiany powodujące mierzalny skutek w postaci pogorszenia warunków poboru lub uzdatniania wody przeznaczonej do spożycia w związku ze zmianami standardów jakości tej wody, o których mowa w art. 50 ust. 1 Ustawy z dnia 18 lipca 2001 r. Prawo wodne, t.j.: Dz.U. z 2012 r., poz. 145 ze zm. (dalej cyt.: u.p.w.). Na podstawie upoważnienia wyrażonego w art. 50 ust. 1 u.p.w. Minister Środowiska wydał cytowane Rozporządzenie w.w.p.d.z.l.w.

${ }_{33}$ M. Michałowski, op. cit., s. 22. Autorka podkreśla, że przy oznaczaniu indeksu fenolowego reakcji ulegają fenole z podstawnikami w pozycji -para, takimi jak: grupa karboksylowa, hydroksylowa, metoksylowa, halogenowa lub sulfonowa, a zatem szeroka grupa różnych związków będących pochodnymi fenolu.

34 Zgodnie z załącznikiem do wydanego na podstawie art. 50 ust. 2 u.p.w. Rozporządzenia Ministra Środowiska z dnia 4 października 2002 r. w sprawie wymagań, jakim powinny odpowiadać wody śródlądowe będące środowiskiem życia ryb w warunkach naturalnych (Dz.U. z 2002 r. Nr 176, poz. 1455, dalej cyt.: w.w.ś.). Zgodnie z § 4 pkt 3 k.o.w.s.w.ś. kryterium oceny wystąpienia szkody w środowisku w wodach jest zmiana lub zmiany powodujące mierzalny skutek w postaci pogorszenia jakości wód śródlądowych stanowiących środowisko życia ryb w warunkach naturalnych oraz wód przybrzeżnych będących środowiskiem życia skorupiaków i mięczaków, o której mowa w art. 50 ust. 2 u.p.w. Na podstawie upoważnienia wyrażonego w art. 50 ust. 2 u.p.w., Minister Środowiska wydał cytowane Rozporządzenie w.w.ś.

35 PN-ISO 6439:1994, s. 4. 
się metody oznaczania indeksu fenolowego w wodach do picia, wodach powierzchniowych i ściekach, można dojść do przekonania, że w przypadku wód, takie podejście jest uzasadnione, jak bowiem wskazano już w jej wstępie: „w wodzie zawierającej fenol występują zwykle również inne związki fenolowe", przy czym „procentowego składu różnych związków fenolowych nie można przewidzieć".

Konkludując powyższe rozważania, należy zatem wyraźnie zaznaczyć, że o ile w sytuacji badania wód czy oceny ich jakości posługiwanie się wskaźnikiem indeksu fenolowego jest prawidłowe, o tyle w momencie badania jakości gleby i ziem, wyrażenie stężenia fenolu za pomocą indeksu fenolowego byłoby istotnym nadużyciem. Rozporządzenie w sprawie standardów jakości gleby i ziemi nie określa dla tego parametru dopuszczalnych stężeń, a tym samym jakakolwiek wartość wyrażona za pomocą indeksu fenolowego nie może stanowić samoistnej przesłanki do stwierdzenia przekroczenia standardów jakości gleby lub ziemi, w tym w szczególności nie może przesądzać o przekroczeniu stężenia fenolu. Jak bowiem akcentowano już wcześniej, na podstawie tego wskaźnika nie można przewidzieć procentowego składu różnych związków fenolowych, więc nie można również przewidzieć składu procentowego samego fenolu.

Mając na względzie powyższe, pomimo faktu, iż w stanie prawnym obowiązującym na dzień 19 marca 2015 r. ustawodawca nie określił referencyjnej metodyki badania stężenia fenolu w glebie lub ziemi, zastosowanie do tego celu metod zamieszczonych w normie PN-ISO 6439:1994 i wyrażenie zawartości fenolu za pomocą indeksu fenolowego należy uznać za niedopuszczalne ${ }^{36}$.

Analizując treść załącznika do rozporządzenia s.j.g.i.z., podkreślenia wymaga, że ustawodawca uzależnił dopuszczalne stężenie fenolu w glebie lub ziemi od przynależności gruntu do

36 Powyższe przesądza również treść samej normy PN ISO6439:1994, w której stwierdza się jednoznacznie, że „metod zamieszczonych w niniejszej normie nie można wykorzystywać do określania zawartości różnych związków fenoli". 
danej grupy, a także od głębokości, na której dokonywany jest pomiar oraz, co zwraca szczególną uwagę - od wodoprzepuszczalności danego gruntu.

Stężenie tej substancji w glebie lub ziemi na nieruchomościach gruntowych przynależnych do grupy „A”, niezależnie od głębokości i wodoprzepuszczalności gruntu, nie powinno przekroczyć $0,05 \mathrm{mg} / \mathrm{kg}$ suchej masy. W przypadku gruntów zaliczonych do grupy „B, dopuszczalna wartość stężenia fenolu w glebie lub ziemi będzie uzależniona od głębokości, a poniżej 0,3 m od poziomu terenu, również od wodoprzepuszczalności ${ }^{37}$ danego gruntu. Do głębokości 0,3 m za dopuszczalne ustawodawca przyjął stężenie fenolu na poziomie $0,1 \mathrm{mg} / \mathrm{kg}$ suchej masy, natomiast poniżej $0,3 \mathrm{~m}$, lecz jednocześnie w warstwach niu przekraczających 15 m poniżej poziomu terenu, o dopuszczalnym stężeniu będzie decydował parametr wodoprzepuszczalności danego gruntu, wyrażony $\mathrm{w}[\mathrm{m} / \mathrm{s}]^{38}$.

Analizując stopień zanieczyszczenia gruntu fenolem na znacznych głębokościach, tj. poniżej $15 \mathrm{~m}$ względem poziomu terenu, dopuszczalne stężenia będą jednakowe zarówno dla terenów przemysłowych, użytków kopalnych czy terenów komunikacyjnych, a zatem gruntów grupy „C”, jak i gruntów zaliczonych do grupy „B”. Dla gruntów obu grup, w przypadku tak głębokiego występowania fenolu, dopuszczalne stężenie będzie uzależnione jedynie od parametru wodoprzepuszczalności ${ }^{39}$.

37 W Rozporządzeniu w sprawie standardów jakości gleby i ziemi ustawodawca posługuje się wyrażonym w [m/s] wskaźnikiem wodoprzepuszczalności gruntów, wskazując jednocześnie, że powoływana w tym rozporządzeniu wartość 1 x $10^{-7}$ odnosi się do wartości przewodnictwa hydraulicznego nasyconego. Ustawodawca pojęć tych jednak nie zdekodował, stąd w dalszej części artykułu wyjaśniono ich znaczenie.

38 Dla gruntów, w których wartość przewodnictwa hydraulicznego nasyconego wynosić będzie do $1 \times 10^{-7}$, dopuszczalne stężenie fenolu określono na poziomie $0,5 \mathrm{mg} / \mathrm{kg}$ suchej masy. W przypadku gruntów, dla których wartość przewodnictwa hydraulicznego nasyconego ustalono poniżej $1 \times 10^{-7}$ stężenie fenolu określono na poziomie $20 \mathrm{mg} / \mathrm{kg}$ suchej masy (a zatem czterdziestokrotnie więcej).

39 Dla gruntów, w których wartość przewodnictwa hydraulicznego nasyconego wynosić będzie do $1 \times 10^{-7}$ dopuszczalne stężenie fenolu określone zostało na poziomie $3 \mathrm{mg} / \mathrm{kg}$ suchej masy, natomiast w przypadku gruntów 
Ponadto odrębnie, dopuszczalne stężenia fenolu określone zostały dla terenów grupy przynależnych do grupy „C”. Dla obszarów przemysłowych, użytków kopalnych i terenów komunikacyjnych, niezależnie od wskaźnika wodoprzepuszczalności gruntu, do $2 \mathrm{~m}$ poniżej poziomu terenu, dopuszczalne stężenie fenolu wynosi $50 \mathrm{mg} / \mathrm{kg}$ suchej masy. Natomiast w warstwach głębszych - do $15 \mathrm{~m}$, dopuszczalne stężenie fenolu również uzależnione będzie od wartości przewodnictwa hydraulicznego nasyconego ${ }^{40}$.

Nie wchodząc nadto szczegółowo w rozważania o charakterze inżynieryjno-technicznym, warto nadmienić, iż wodoprzepuszczalność, oznaczana symbolem „k”, stanowi zdolność gruntu do przepuszczania wody przez pory gruntowe. Polska Norma, definiuje wskaźnik wodoprzepuszczalności (współczynnik filtracji) ${ }^{41}$ jako „prędkość przepływu wody w odniesieniu do całego przekroju gruntu przy spadku hydraulicznym ${ }^{42}$ równym jedności". W literaturze przedmiotu ${ }^{43}$ podkreśla się, iż wskaźnik wodoprzepuszczalności, określający zdolność do przewodzenia wody przez ośrodki porowate $\mathrm{w}$ tym glebę i ziemię, stanowi jeden z najważniejszych parametrów charakteryzujących grunty. Autor przedstawionego poglądu podkreśla nadto, iż wartość współczynnika filtracji, jako cecha swoista danego rodzaju gruntu, będzie zależna przede wszystkim od jego uziarnienia czi porowatości, jak również od temperatury wody przepływa-

o wartości przewodnictwa hydraulicznego nasyconego poniżej $1 \times 10^{-7}$ dopuszczalne stężenie fenolu wyniesie $40 \mathrm{mg} / \mathrm{kg}$ suchej masy.

40 Dopuszczalne stężenie fenolu wyniesie $3 \mathrm{mg} / \mathrm{kg}$ suchej masy dla gruntów, których wartość przewodnictwa hydraulicznego nasyconego wynosić będzie do $1 \times 10^{-7}$ i $100 \mathrm{mg} / \mathrm{kg}$ suchej masy przy wartości przewodnictwa hydraulicznego nasyconego poniżej $1 \times 10^{-7}$.

41 Zdefiniowany w Polskiej Normie wskaźnik wodoprzepuszczalności przy spadku hydraulicznym równym jedności zamiennie nazywany jest współczynnikiem filtracji; z powyższego - przewodnictwo hydrauliczne nasycone określa się również jako współczynnik filtracji.

42 Spadek hydrauliczny, inaczej gradient hydrauliczny, oznacza stosunek różnicy wysokości wody gruntowej do długości jej przepływu, http://encyklopedia.pwn.pl/haslo/3907357/gradient-hydrauliczny.html [dostęp: 11 marca 2015].

43 A. Wieczysty, Hydrogeologia inżynierska, Łódź 1970, s. 297. 
jącej przez dany ośrodek ${ }^{44}$. Jednocześnie warto nadmienić, że dokładność wyznaczenia współczynnika wodoprzepuszczalności, a zatem określenia wartości przewodnictwa hydraulicznego nasyconego, zarówno metodami laboratoryjnymi, ale i polowy$\mathrm{mi}^{45}$, „napotyka na podstawową trudność, wynikającą z braku metody wzorcowej, dającej wyniki całkowicie ścisłe, do których można by porównać inne metody ${ }^{46 "}$. Co więcej, przedstawiciele nauki ${ }^{47}$ wskazują, iż wyniki uzyskane w tych samych ośrodkach porowatych, przy zastosowaniu różnych metod, dają istotnie różne wartości współczynnika filtracji.

$\mathrm{Na}$ tle poczynionych rozważań, nasuwa się wniosek, że dla określenia dopuszczalnego stężenia fenolu w danym grunci, niezwykle istotne znaczenie, poza oczywistą koniecznością uwzględnienia aktualnej i planowanej funkcji terenu, będzie miało prawidłowe określenie współczynnika wodoprzepuszczalności, co - jak dostrzeżono - może nastręczać pewnych trudności. To jednak właśnie ten, wyrażony wartością przewodnictwa hydraulicznego nasyconego, parametr, ustawodawca uznał za czynnik decydujący o dopuszczalnej wartości stężenia fenolu ${ }^{48}$.

Warto podkreślić, co sygnalizowano już wcześniej, iż zgodnie z $\S 1$ ust. 4 rozporządzenia s.j.g.i.z, ,jeżeli przekroczenie wartości dopuszczalnej stężenia substancji w badanej glebie lub ziemi wynika z naturalnie wysokiej jej zawartości w środowisku, uważa się, że przekroczenie dopuszczalnej wartości stężeń w glebie lub ziemi nie nastąpiło". Dla stwierdzenia zatem przekroczenia standardów jakości gleby lub ziemi, a zatem również ewentualnego wystąpienia szkody w powierzchni ziemi, kluczowe znaczenie będzie miało również jednoznaczne ustalenie

44 Ibidem, s. 297.

45 Szerzej na temat metod określania współczynnika wodoprzepuszczalności zob. A. Wieczysty, op. cit., s. 297-307.

46 A. Wieczysty, op. cit., s. 297.

47 J. Nieć, M. Spychała, Hydraulic Conductivity Estimation Test Impact on Long-Term Acceptance Rate and Soil Absorption System Design, „Water” 2014, nr 6, s. 2808-2820.

48 Powyższe spostrzeżenie pozostaje aktualne również $\mathrm{w}$ odniesieniu do pozostałych substancji wymienionych w załączniku do Rozporządzenia w sprawie standardów jakości gleby i ziemi. 
pochodzenia analizowanej substancji. Wskazać bowiem należy, co podkreślają również przedstawiciele nauki ${ }^{49}$, że obowiązek rekultywacji nie może być nałożony w odniesieniu do gleb terenów z natury zasobnych np. w pierwiastki toksyczne. Autorzy publikacji ${ }^{50}$ opracowanej w Instytucie Uprawy Nawożenia i Gleboznawstwa w Puławach jednoznacznie stwierdzają, że „jeżeli przekroczenie wartości dopuszczalnej stężenia substancji w badanej glebie lub ziemi wynika z naturalnie wysokiej jej zawartości w środowisku, uważa się, że przekroczenie dopuszczalnej wartości stężeń w glebie lub ziemi nie nastąpiło". Reasumując, w odniesieniu do takich obszarów, nie będzie także możliwe stwierdzenie wystąpienia szkody w powierzchni ziemi.

Odnosząc powyższe rozważania do ewentualnego zanieczyszczenia gleby lub ziemi fenolem należy zauważyć, iż poczyniona uwaga może mieć kluczowe znaczenie. Trzeba bowiem wskazać, że na wielu terenach przekroczenie wartości stężeń określonych jako standardy jakości gleby lub ziemi nie jest efektem negatywnego oddziaływania podmiotów korzystających ze środowiska, a ma charakter naturalny i wynika ze specyficznych uwarunkowań, nierzadko o charakterze lokalnym. W przypadku fenolu, w literaturze przedmiotu ${ }^{51}$ wyraźnie podkreśla się, iż nagromadzeniu tego związku w glebie sprzyja m.in. uprawa roślin $\mathrm{w}$ monokulturze ${ }^{52}$. W prowadzonych w tym zakresie badaniach naukowych ${ }^{53}$ zaobserwowano, że związki fenolowe,

49 T. Stuczyński, G. Siebielec, B. Maliszewska-Kordybach, B. Smreczak, L. Gawrysia, Wyznaczanie obszarów, na których przekroczone sq standardy jakości gleb. Poradnik metodyczny dla administracji, Warszawa 2004, s. 32.

50 Ibidem, s. 45.

51 J. Furczak, B. Turska, Wpływ różnych systemów uprawy soi na rozwój mikroorganizmów i zawartość fenoli w glebie płowej, „Acta Agrophysica” 2006, nr 1, s. 59-68.

52 Monokultura to system rolniczy polegający na wieloletnim uprawianiu na tym samym obszarze roślin jednego gatunku. Słownik Języka Polskiego PWN [online], http://sjp.pwn.pl/slownik/2568345/monokultura [dostęp: 14 marca 2015].

53 M. Hruszka, Studia nad toksycznością związków fenolowych $w$ uprawach monokulturowych, „Acta Universitatis Agriculturae. Facultas agronomica”, Brno 1982, z. 3, s. 79-85. 
w tym fenol, są jednym z czynników tzw. „zmęczenia gleby”54 w monokulturach i spadku plonowania roślin. W sposób naturalny, fenol występuje w wielu glebach, a najwyższe wartości stężeń, wskaźnik ten osiąga w okresie intensywnego rozwoju roślin. Taki stan rzeczy, zdaniem niektórych autorów ${ }^{55}$, może być związany m.in. z postępującym rozkładem resztek roślinnych. Powyższy pogląd podziela również M. Michałowskiis, podkreślając, iż poziom fenolu w glebie podnosi wieloletni brak płodozmianu, co jest szczególnie widoczne w przypadku uprawy żyta, owsa, jęczmienia, ziemniaków czy kukurydzy, a także zbyt długie zaleganie resztek tego rodzaju roślin na polach.

Rezultaty badań M. Hruszki ${ }^{57}$ jednoznacznie wskazują, że okres pełnego rozwoju roślin sprzyja gromadzeniu się fenoli w glebie. Z przeprowadzonych przez autorkę badań wynika, że zawartość związków fenolowych w glebach użytkowanych rolniczo może być bardzo znaczna, a jednocześnie istotnie zróżnicowana bo waha się w przedziale $0,9-1,5 \mathrm{mg} / \mathrm{kg}$ suchej masy gleby w zależności od fazy rozwoju roślin oraz sposobu uprawy. Przyjmując, że zawartość związków fenolowych w badanej glebie odzwierciedla w pewnym stopniu zawartość czystego fenolu, choć jednocześnie podtrzymując poczynioną uprzednio uwagę, iż w przypadku fenolu, ewentualne naruszenie dotyczyć może jedynie samego fenolu, a nie związków fenolowych, a także uwzględniając określone w załączniku do Rozporządzenia s.j.g.i.z. dopuszczalne stężenie fenolu, można by dojść do przekonania, że $\mathrm{w}$ takiej sytuacji nastąpiło przekroczenie standardów jakości gleby lub ziemi w odniesieniu do tego parametru. Powyższe byłoby oczywistym błędem w sytuacji, gdy

54 Zmęczenie gleby to obniżenie się urodzajności gleby wskutek częstej uprawy jednego gatunku rośliny w tym samym miejscu. Słownik Języka Polskiego PWN [online], http://sjp.pwn.pl/slownik/2546654/zm\%C4\%99czenie_gleby [dostęp: 14 marca 2015].

55 M. Hruszka, Związki fenolowe jako jeden z czynników zmęczenia gleby, Zeszyty naukowe Akademii Rolniczo-Technicznej w Olsztynie, „Agriculture” 1987, vol. 44, s. 257-267.

56 M. Michałowski, op. cit., s. 21.

57 Zob. zarówno M. Hruszka, Studia nad toksycznością, s. 79-85; M. Hruszka, Związki fenolowe jako jeden z czynników, s. 257-267. 
źródłem fenolu występującego w znacznych stężeniach, byłoby jego naturalne nagromadzenie, wynikające np. z postępującego rozkładu resztek roślinnych.

W przypadku wielu zanieczyszczeń, kluczowe dla prawidłowego określenia, czy w konkretnej sytuacji wystąpiła szkoda w powierzchni ziemi, jest również wskazanie daty wystąpienia szkody. To bowiem wskazanie daty może mieć kluczowe znaczenie dla określenia sprawcy szkody, a co się z tym wiąże również oceny, czy w rozumieniu przepisów u.z.s.w.s, mamy do czynienia ze szkodą w środowisku, czy może z tzw. zanieczyszczeniem historycznym powierzchni ziemi ${ }^{58}$.

Sprowadzając powyższe rozważania do przykładu fenolu, warto wskazać na pewną szczególną właściwość tej substancji jaką jest biodegradowalnośćs9. W literaturze wskazuje się, iż fenol jest substancją bardzo szybko ulegającą biodegradacji, a spośród węglowodorów jednopierścieniowych, jest związkiem jednym z bardziej podatnych na rozkład przez bakterie ${ }^{60}$. W ramach prowadzonych badań, Ż. Swędzioł i A. Mrozik ${ }^{61}$ wykazały, iż pewne, występujące $\mathrm{w}$ glebach szczepy bakterii, całkowicie rozkładają fenol występujący w stężeniu 1,700 mg/g suchej masy, a zatem powyżej wartości określonych jako standardy ja-

58 Zgodnie z art. 4 pkt 1 Ustawy szkodowej jej przepisów nie stosuje się do historycznego zanieczyszczenia powierzchni ziemi, które w art. 3 pkt 5a u.p.o.ś. ustawodawca definiuje jako zanieczyszczenie powierzchni ziemi, które zaistniało przed dniem 30 kwietnia 2007 r. lub wynika z działalności, która została przed tym dniem zakończona; historycznym zanieczyszczeniem powierzchni ziemi będą również szkody w środowisku w powierzchni ziemi w rozumieniu art. 6 pkt 11 lit. c Ustawy szkodowej, które zostały spowodowane przez emisję lub zdarzenie, od którego upłynęło więcej niż 30 lat.

59 „Biodegradacja” [gr.-łac] to rozkład substancji chemicznych na wodę i dwutlenek węgla oraz proste, nietoksyczne związki chemiczne, zachodzący pod wpływem mikroorganizmów. Encyklopedia PWN [online], http:// encyklopedia.pwn.pl/haslo/3877794/biodegradacja.html [dostęp: 14 marca 2015].

${ }^{60}$ A. Mrozik, Zmiany $w$ składzie bakteryjnych kwasów tłuszczowych $w$ czasie rozkładu fenolu $w$ glebie, „Prace Naukowe Uniwersytetu Śląskiego w Katowicach" nr 2689, Katowice 2009, s. 10.

61 Ż. Swędzioł, A. Mrozik, Profile kwasów tłuszczowych dzikiego i modyfikowanego genetycznie szczepu Pseudomonasvesicularis $w$ czasie rozkładu fenolu w glebie, „Nauka, Przyroda, Technologie” 2010, nr 4, s. 96. 
kości dla gleby i ziemi gruntów grupy „A” i niektórych gruntów grupy „B”, w ciągu zaledwie 20 dni. Odwołując się do aktów normatywnych, trudno nie dostrzec analogii $\mathrm{w}$ znaczeniu terminu „biodegradacja” i zdefiniowanym w art. 3 pkt 32d u.p.o.ś. pojęciu „samooczyszczanie”, które ustawodawca odnosi do biologicznych, chemicznych, fizycznych procesów, jakich skutkiem jest ograniczenie ilości, ładunku, stężenia, toksyczności, dostępności oraz rozprzestrzeniania się zanieczyszczeń w glebie, ziemi oraz wodach. Podkreślenia wymaga, że samooczyszczanie w rozumieniu art. 3 pkt $32 d$ u.p.o.ś., zachodzi bez ingerencji człowieka, a także ma przebieg samoistny, choć może być przez człowieka wspomagane. Tak pojmowane samooczyszczanie, jako naturalna regeneracja ${ }^{62}$, która w odniesieniu do powierzchni ziemi stanowi usunięcie zagrożenia dla zdrowia ludzi i stanu środowiska, jest postrzegana przez ustawodawcę jako naprawa elementów przyrodniczych ${ }^{63}$.

W świetle poczynionych spostrzeżeń należy stwierdzić, że wskazanie związku przyczynowego pomiędzy działalnością prowadzoną przez dany podmiot korzystający ze środowiska, a skutkiem w postaci szkody przejawiającej się przekroczeniem dopuszczalnego stężenia fenolu w glebie lub ziemi, może być niezwykle trudne, a w niektórych sytuacjach wręcz niemożliwe. Znajomość powyższych faktów może mieć zatem kluczowe znaczenie dla oceny, czy w danej sytuacji w ogóle wystąpiła szkoda $\mathrm{w}$ środowisku, $\mathrm{w}$ tym $\mathrm{w}$ szczególności szkoda $\mathrm{w}$ powierzchni ziemi.

62 Zgodnie z art. 6 pkt 8a lit. b u.z.s.w.s. naturalna regeneracja to, w odniesieniu do wód i powierzchni ziemi, samooczyszczanie w rozumieniu art. 3 pkt 32d u.p.o.ś.

63 Zgodnie z art. 6 pkt 8 lit. c u.z.s.w.s. naprawa elementów przyrodniczych, która obejmuje również naturalną regenerację to, w odniesieniu do powierzchni ziemi, usunięcie zagrożenia dla zdrowia ludzi i stanu środowiska. 


\section{PODSUMOWANIE}

Nakreślone powyżej studium przypadku, bazujące wprost na aktach normatywnych, bez wątpienia nie wyczerpuje tematyki szkody w powierzchni ziemi objawiającej się przekroczeniem standardów jakości gleby i ziemi w tym, w szczególności określonych dla fenolu. Celem przedstawionych rozważań nie było jednak zgłębienie tej skomplikowanej materii, a jedynie zilustrowanie na konkretnym przykładzie rozwiązań regulujących zagadnienie szkody w powierzchni ziemi, a także kryteriów jej wystąpienia przyjętych przez polskiego ustawodawcę.

Uwzględniając specyficzne właściwości tylko jednej, wybranej substancji, uwypuklono znaczenie dorobku nauk pozaprawnych dla prawidłowego wskazania odpowiedzialnego za szkodę podmiotu korzystającego ze środowiska, jak również możliwości wykluczenia z kręgu podmiotów odpowiedzialnych za taką szkodę. Powyższy przykład, prowadzi również do refleksji, iż zagadnienie szkody w powierzchni ziemi, w szczególności prawidłowa ocena jej wystąpienia, a także wskazanie podmiotów odpowiedzialnych za szkodę, stanowi wprawdzie bazujący na regulacjach prawnych, jednak nierzadko wymagający również posiłkowania się wiedzą specjalistyczną, skomplikowany proces o interdyscyplinarnym charakterze.

\section{BIBLIOGRAFIA}

Bogda A., Mineralogiczne i mikromorfologiczne badania produktów wietrzenia niektórych magmowych skał macierzystych gleb występujacych w Sudetach, „Roczniki Gleboznawcze” 1973, nr 2.

Bojarska K., Bzowski Z., Monitoring środowiska rejonie składowiska odpadów komunalnych w Zakopanem, „Ochrona Środowiska i Zasobów Naturalnych" 2009, nr 40.

Federczyk W., Kosieradzka-Federczyk A., Ustawa o zapobieganiu szkodom $w$ środowisku i ich naprawie. Komentarz, LEX/el. 2013.

Furczak J., Turska B., Wptyw różnych systemów uprawy soi na rozwój mikroorganizmów i zawartość fenoli w glebie płowej, „Acta Agro-

3/2015 physica” 2006, nr 1. 
Górski M., Odpowiedzialność administracyjnoprawna w ochronie środowiska, Warszawa 2008.

Hruszka M., Studia nad toksycznością związków fenolowych w uprawach monokulturowych, „Acta Universitatis Agriculturae. Facultas agronomica", Brno 1982, z. 3.

Hruszka M., Związki fenolowe jako jeden z czynników zmęczenia gleby, „Zeszyty Naukowe Akademii Rolniczo-Technicznej w Olsztynie. Agriculture" 1987, vol. 44.

Kaleta J., Papciak D., Puszkarewicz A., Ocena przydatności iłołupków bentonitowych do usuwania fenolu z roztworów wodnych, „Rocznik Ochrona Środowiska" 2013, vol. 15.

Kwaśnicka K., Odpowiedzialność administracyjna w prawie ochrony środowiska, Warszawa 2011.

Mazurski K., Fitogeniczne gleby Sudetów w świetle badań masowych, „Roczniki Gleboznawcze” 1978, nr 2.

Michałowski M., Analiza zanieczyszczeń związkami fenolowymi górnego dorzecza Raby i Dunajca oraz ustalenie źródeł emisji tych związków, „Inżynieria Mineralna” 2011, nr 1.

Mrozik A., Zmiany $w$ składzie bakteryjnych kwasów tłuszczowych $w$ czasie rozkładu fenolu $w$ glebie, „Prace Naukowe Uniwersytetu Śląskiego w Katowicach" nr 2689, Katowice 2009.

Nieć J., Spychała M., Hydraulic Conductivity Estimation Test Impact on Long-Term Acceptance Rate and Soil Absorption System Design, „Water” 2014, nr 9.

Rakoczy B., Cywilnoprawne aspekty ustawy o zapobieganiu szkodom $w$ środowisku $i$ ich naprawie, „Studia z zakresu prawa, administracji i zarządzania Uniwersytetu Kazimierza Wielkiego w Bydgoszczy" 2013, vol. 3.

Rakoczy B., Komentarz do art. 103 ustawy - Prawo ochrony środowiska, [w] Z. Bukowski, E. K. Czech, K. Karpus, B. Rakoczy, Prawo ochrony środowiska Komentarz, Warszawa 2013.

Rakoczy B., Komentarz do ustawy o zapobieganiu szkodom w środowisku u ich naprawie, Warszawa 2008.

Sas W., Maciorowska E., Permeability coefficient of recycled concrete aggregate as an anthropogenic soil tested in laboratory by constant head method. Scientific Review, „Engineering and Environmental Sciences" 2012, nr 58.

Stuczyński T., Siebielec G., Maliszewska-Kordybach B., Smreczak B., Gawrysia L., Wyznaczanie obszarów, na których przekroczone sq standardy jakości gleb. Poradnik metodyczny dla administracji, Warszawa 2004. 
Swędzioł Ż., Mrozik A., Profile kwasów tłuszczowych dzikiego i modyfikowanego genetycznie szczepu Pseudomonasvesicularis $w$ czasie rozkładu fenolu w glebie, „Nauka, Przyroda, Technologie” 2010, nr 4.

Szczuka-Skarżyńska W., Nasze wspólne dobro, „Rzeczpospolita” 2003/7/2.

Wieczysty A., Hydrogeologia inżynierska, Łódź 1970.

Wojcieszyńska D., Wilczek A. Związki fenolowe pochodzenia naturalnego, „Nauka i Technika” 2006, nr 6.

Kontakt e-mail:

anianiec@wp.pl 